Dhaka Univ. J. Biol. Sci. 23(1): 1-8, 2014 (January)

\title{
EFFECTS OF WASTE WATER IRRIGATION ON THE GROWTH AND NUTRIENT STATUS OF KALMI (IPOMOEA AQUATICA FORSSK.)
}

\author{
Md. Jamal Uddin ${ }^{1}$, Shamim Al Mamun², Ashrafun Nessa², Zakia Parveen \\ AND S.M. IMAMUL HuQ* \\ Department of Soil, Water and Environment, University of Dhaka, Dhaka-1000, Bangladesh \\ Key words: Waste water, Ipomoea aquatica, Heavy metal, Nutrient status
}

\begin{abstract}
A pot experiment was carried out to observe the effect of waste water irrigation on the growth and nutrient status of Kalmi (Ipomoea aquatica) in the nethouse of the Department of Soil, Water and Environment, University of Dhaka. The soil samples were collected from Tejgaon, Rampura, Sitalakhya and from the north-side of Rampura area, the latter is located at a distance from the polluted area and has been used as the control soil. The pots containing the first three soil samples were irrigated with wastewater collected from the adjacent industrial area and control pots were irrigated with tap water. The plants on Tejgaon soil produced the maximum biomass while the plants on Sitalakhya produced the least amount of biomass. The accumulation of toxic metal concentration was found to be the highest in Kalmi grown on Tejgaon followed by Rampura and Sitalakhya. The metal concentration in Kalmi (dry weight basis) ranged between $31 \mathrm{and} 408 \mathrm{mg} / \mathrm{kg}$ for $\mathrm{Zn}, 27$ to $45 \mathrm{mg} / \mathrm{kg}$ for $\mathrm{Cu}, 0.2$ to $5.0 \mathrm{mg} / \mathrm{kg}$ for $\mathrm{Pb}$ and 0 to 2 $\mathrm{mg} / \mathrm{kg}$ for Cd, respectively. The concentrations of heavy metals in the Kalmi were higher than the recommended standards in all the treatments except control.
\end{abstract}

\section{Introduction}

Increased urbanization and industrialization in the developing countries have been the cause of production of a large volume of waste water and effluents the disposal of which is becoming a growing concern ${ }^{(1)}$. On the other hand, application of wastewater to crop land could be an alternative source of nutrients because it can improve physical properties and increase nutrient contents of soils(2). Irrigation with waste water has been reported to provide $\mathrm{N}, \mathrm{P}$ and organic matter to the soils ${ }^{(3)}$. Nevertheless, there is a risk of potential toxic elements such as $\mathrm{Cd}, \mathrm{Pb}, \mathrm{Cu}, \mathrm{Zn}, \mathrm{Fe}$ and $\mathrm{Mn}$ accumulation from domestic and industrial sources ${ }^{(4)}$. The occurrence of significant level of heavy metals in industrial waste water that are discharged into surface water can have deleterious effects on the environment and public health. A high concentration of these heavy metals in plant tissues can harbour poisoning problems in human beings and other animals feeding on

*Author for correspondence: <imamhuq@hotmail.com>. 1Barisal University, Barisal, Bangladesh. ${ }^{2}$ Mawlana Bhashani Science and Technology University, Santosh, Tangail-1902, Bangladesh. 
them ${ }^{(1)}$. Heavy metal accumulation in plants depends upon plant species, and the efficiency of different plants in absorbing metals had been evaluated by either plant uptake or soil-to plant transfer factors of the metals ${ }^{(5)}$. The concentrations of heavy metals in plants also depend on application rate of waste water, soil reactions etc. ${ }^{(6)}$.

Ipomoea aquatica, commonly known as Kalmi shak, is one of the indigenous and widely consumed leafy vegetables in Bangladesh. Ipomoea aquatica represents one of the richest sources of carotenoids and chlorophylls( ${ }^{(7)}$. The leaves of Kalmi contain adequate quantities of most of the essential amino acids in line with the WHO recommendation pattern for an ideal dietary protein ${ }^{(8)}$. Therefore, it could be treated as a potential food supplement particularly in the rural area. However, different workers reported significant accumulation of toxic heavy metals in different plant parts of Kalmi ${ }^{(9-11)}$. Moreover, this plant is a popularly grown and consumed leafy vegetable in rural, perurban and urban areas of Bangladesh. The lands near the industrial belts of Tejgaon, Rampura and Sitalakhya are used to grow this crop with the waste waters coming from various industrial units. Thus, it became pertinent to use this plant as the test crop for the present experiment. The current research was undertaken to determine the contamination status of heavy metals in edible part of Kalmi grown on industrially polluted soils around Dhaka city and also to observe the transfer of heavy metals from waste water to soil-plant system.

\section{Materials and Methods}

The experiment was conducted in the Department of Soil, Water and Environment (SWE), University of Dhaka. The study was carried out to evaluate the status of heavy metals in water of the Tejgoan Khal, Rampura Canal-Balu River and Sitalakhya River and their subsequent transfer to the plant Ipomoea aquatica. All experiments were carried out in triplicates. The sampling sites are shown in Fig. 1.

The soils were collected at $0-15 \mathrm{~cm}$ depth from adjacent fields of Tejgaon Khal, Rampura Canal, Sitalakhya River and from Kayet para near Rampura. The soils belong to the Tejgaon series (Manjurul Haque, personal communication). The soil samples were dried in air for 3 days. Visible roots and debris were removed. After air-drying, a portion of the larger and massive aggregates were broken by a wooden hammer. Approximately $500 \mathrm{gm}$ of each sample was taken for chemical and physico-chemical analysis which was screened to pass through a $2 \mathrm{~mm}$ stainless steel sieve. A portion of the soil samples was further ground and screened to pass through a $0.5 \mathrm{~mm}$ sieve. The sieved samples were mixed thoroughly for making composite samples and preserved.

Water samples for irrigation were collected in large plastic pots from the corresponding water bodies of the Tejgoan, Rampura and Shitalakhya areas. The points of water collection were selected wherefrom soil samples were collected. Tap water from the Department of SWE was used for control plants. For laboratory analysis two sets of 
samples were collected in plastic bottles of which one set was mixed with 4 - 5 drops of $\mathrm{HNO}_{3}$ acid and another set for BOD, COD, DO, and $\mathrm{pH}$ from each point.

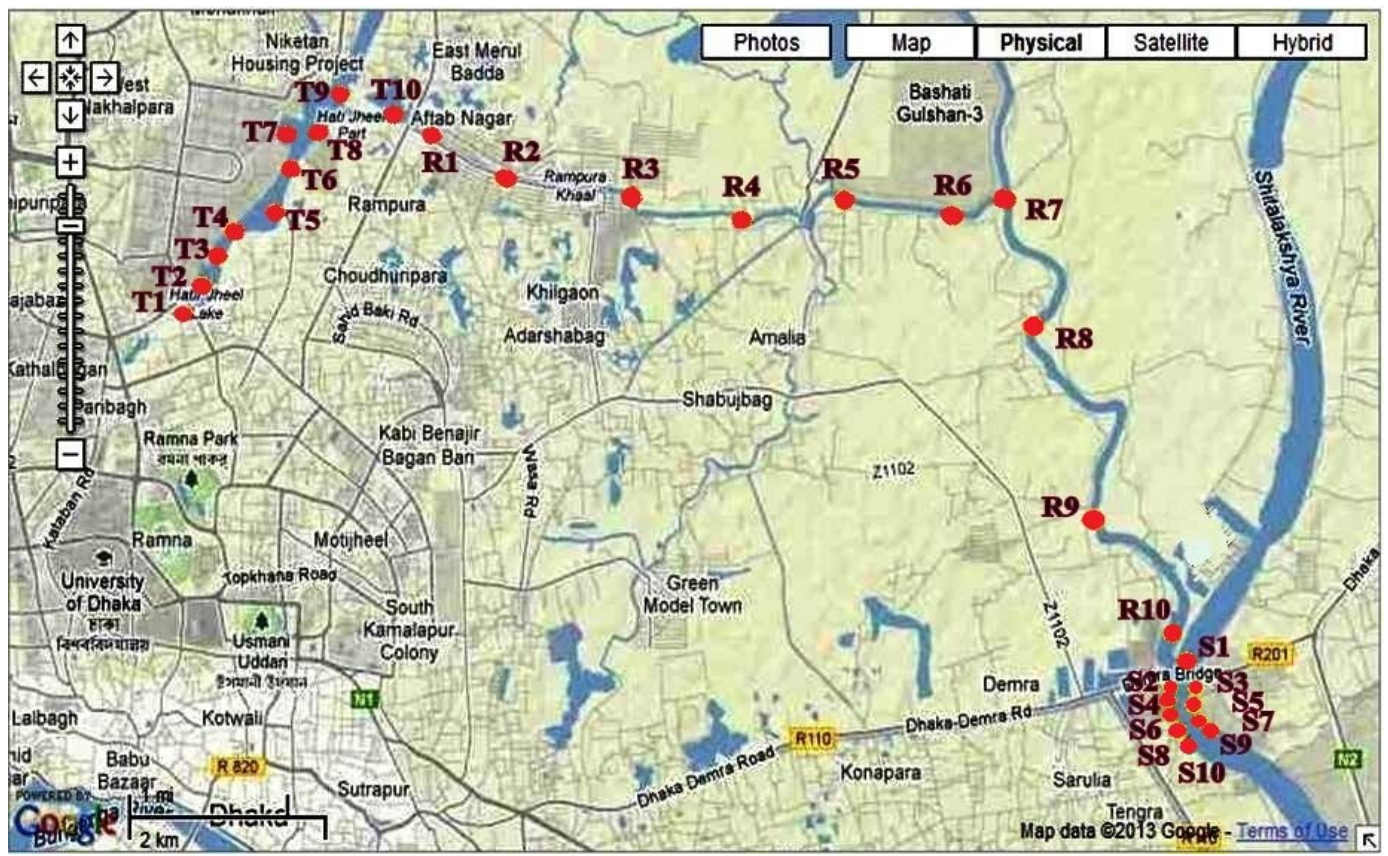

Fig. 1. Sampling points of studied area.

To set up the experiment all plastic pots were filled up with $5 \mathrm{~kg}$ of air-dried soil. Before seeding all the needed fertilizers (Urea, MP and TSP) were mixed in the soil of the pot.

Seeds of Kalmi were collected from BADC. About ten seeds were sown in each of the pots and allowed to germinate. One week after germination, thinning was done and four plants were allowed to grow. Watering of the pots was made twice in a day and the position of the pots were changed every alternate day to expose them to adequate sunlight.

The plants were allowed to grow for 35 days. After this time, the plants were collected by uprooting them from the pots. After removing the extra soil adhering to the roots, the roots were washed three times with 1 min washings of each in 1 litre distilled water to make the roots free from ions in the ion free space of the roots. The plant samples were separated into two parts such as root and edible parts. The fresh weights of the collected samples were noted. For chemical analysis, the samples were first air dried and then oven dried at $70 \pm 5^{\circ} \mathrm{C}$ for 48 hours and then dry weight of the plant samples were taken. The samples were ground with an electric grinder and passed through a 0.2 
$\mathrm{mm}$ sieve. The ground samples were mixed thoroughly to make it a composite one and the ground samples were preserved in a dry place.

After harvesting of plants, the soil samples from each of the pots were collected and processed as described earlier.

Various physical, chemical and physico-chemical properties of the soil samples were analyzed in the laboratory as described by Imamul Huq and Alam ${ }^{(12)}$. All elements of plant samples were calculated on oven dry basis. The data were subjected for statistical analysis for ANOVA using SPSS-16 software.

\section{Results and Discussion}

The soil and water samples thus collected were analyzed for various parameters and the results are presented in Tables 1 and 2.

Table 1. Physical, chemical and physico-chemical properties of the soil.

\begin{tabular}{lcccc}
\hline Properties & \multicolumn{3}{c}{ Soil } \\
\cline { 2 - 5 } & Control & Tejgaon & Rampura & Sitalakhya \\
\hline Textural class & SCL & SL & L & SCL \\
pH & 4.40 & 5.90 & 4.84 & 6.24 \\
Moisture content (\%) & 4.73 & 7.62 & 4.96 & 2.88 \\
Organic C " & 1.07 & 6.28 & 1.90 & 0.95 \\
Available N (mg/kg) & 673.9 & 504.2 & 586.5 & 308.7 \\
Available P " & 8.72 & 4.0 & 6.10 & 12.17 \\
Available K " & 195.65 & 285.38 & 36.71 & 34.15 \\
Total N (\%) & 0.185 & 1.07 & 0.17 & 0.12 \\
Total P " & 0.06 & 0.19 & 0.15 & 0.10 \\
Total K " & 0.13 & 0.23 & 0.17 & 0.16 \\
Total S " & 0.11 & 0.13 & 0.14 & 0.12 \\
Total Zn (mg/kg) & 72.38 & 530.38 & 87 & 86 \\
Total Cu " & 33.70 & 97.72 & 63 & 36.24 \\
Total Pb " & 14.85 & 51.80 & 26.90 & 17.75 \\
Total Cd " & BDL & 0.52 & 0.60 & 0.12 \\
\hline
\end{tabular}

$\mathrm{BDL}=$ Below detection limit $\mathrm{L}=\mathrm{Loam}, \mathrm{SCL}=$ Silty clay loam, $\mathrm{SL}=$ Silty loam.

The growth is expressed both as fresh and dry weight basis for the edible part of the plant. The results for the fresh matter and dry matter yield grown on different soils and irrigated with waste water are presented in Table 3. The yield of edible part grown on Rampura soil showed a significant difference $(\mathrm{p} \leq 0.05)$ with that of control soil plants whereas the yield of the plants grown on Tejgaon and Sitalakhya showed no significant difference. The least biomass production was observed for the plants grown on 
Sitalakhya soil. The reason could be related to low organic matter and nitrogen content compared to the other soils.

Table 2. Physical, chemical and physico-chemical properties of waste water.

\begin{tabular}{lcccc}
\hline Properties & \multicolumn{4}{c}{ Waste water } \\
\cline { 2 - 5 } & Control & Tejgaon & Rampura & Sitalakhya \\
\hline $\mathrm{pH}$ & 7.2 & 7.15 & 6.90 & 7.30 \\
$\mathrm{BOD}(\mathrm{mg} / \mathrm{kg})$ & 6.25 & 520 & 480 & 110 \\
$\mathrm{COD} "$ & 7.49 & 430 & 300 & 190 \\
$\mathrm{DO} "$ & 6.62 & 0.33 & 0.37 & 2.69 \\
TDS " & 215 & 1158 & 1108 & 781 \\
Ammonia- N " & 1.12 & 2.71 & 2.65 & 0.53 \\
Total P " & 0.06 & 14.68 & 7.20 & 6.04 \\
Total K " & 0.09 & 12.92 & 12.29 & 3.29 \\
Total S " & 0.23 & 7.93 & 4.84 & 2.28 \\
Total Zn " & 0.01 & 0.12 & 0.15 & 0.02 \\
Total Cu " & BDL & 0.01 & 0.03 & 0.001 \\
Total Pb " & BDL & 0.56 & 0.07 & BDL \\
Total Cd " & BDL & 0.13 & 0.17 & 0.13 \\
\hline
\end{tabular}

$\mathrm{BDL}=$ Below detection limit.

The growth parameters and elemental composition of kalmi as affected by waste water treatment are presented in Table 3.

The data in Table 3 indicate that the concentration of total nitrogen was higher in Kalmi grown on Tejgaon (T), Rampura (R) and Sitalakhya (S) soil compared to control soil. This could partially be due to higher concentration of the particular element in the waste water. Nevertheless, the $\mathrm{N}$ concentration in Kalmi grown on Tejgaon, Rampura and Sitalakhya did not show any significant difference while comparing with control soil. Meanwhile, the concentration of $\mathrm{P}$ in plants grown on Rampura and Sitalakhya soils were found higher than that of control plants whereas those grown on Tejgaon soil contained less $\mathrm{P}$ than control. The concentration of $\mathrm{P}$ in the plants on Tejgaon soil was significantly different from the $\mathrm{P}$ concentration of control plants $(\mathrm{p} \leq 0.05)$. The $\mathrm{K}$ concentration was the highest in control plants. There has been a decrease in the concentration of $\mathrm{K}$ in plants grown on other soils. The potassium concentration in Kalmi grown on Tejgaon, Rampura and Sitalakhya soils $(\mathrm{p} \leq 0.05)$ varied significantly from that of control plants. The concentration of sulphur in Kalmi was found to be the lowest $(0.131 \%)$ in Rampura soil. Meanwhile the maximum sulphur percentage (0.170) was recorded for control soil compared to the other three soils. The sulphur concentration in the plants grown on the other three soils varied significantly $(p \leq 0.05)$ from control plants. 
From Table 3 it can be seen that $\mathrm{Zn}$ concentration $(407.88 \mathrm{mg} / \mathrm{kg})$ was the highest in plants growing on Tejgaon soil while the control plants contained the least amount of $\mathrm{Zn}$ (30.98 mg/kg). The values for $\mathrm{Zn}$ concentrations exceeded the standard value $(20 \mathrm{mg} / \mathrm{kg}$ ) in crops although the typical range is $6-75 \mathrm{mg} / \mathrm{kg}^{(12)}$. This could hamper plant's normal growth. The higher concentration of $\mathrm{Zn}$ might be due to the higher concentration of $\mathrm{Zn}$ in Tejgaon, Rampura and Shitalakhya soil which were irrigated with the waste water. The $\mathrm{Cu}$ concentrations in the plants growing on different soils were higher compared to the control plants. The highest concentration $(49.62 \mathrm{mg} / \mathrm{kg})$ was found in the plants growing on Rampura soil. The $\mathrm{Cu}$ concentration in the plants growing on the contaminated soils was significantly different $(\mathrm{p} \leq 0.05)$ from the $\mathrm{Cu}$ content of control plants. The $\mathrm{Pb}$ concentrations in the plants growing on Tejgaon and Rampura soils were more than allowable limit which might cause toxic effect to human health. A substantial increase in $\mathrm{Pb}$ concentration was observed in the plants grown on these two soils that varied significantly from that of the control plants $(\mathrm{p} \leq 0.05)$. Waste water irrigation also caused significant accumulation of $\mathrm{Cd}$ in the plants. A maximum of $(2.05 \mathrm{mg} / \mathrm{kg}) \mathrm{Cd}$ was found in the plants grown on Tejgaon soil. The $\mathrm{Cd}$ concentrations in plants grown on the contaminated soil were significantly higher than that of the control plants $(\mathrm{p} \leq 0.05)$.

Table 3. Effect of waste water irrigation on the growth and nutrient content of Kalmi.

\begin{tabular}{lccccccccccc}
\hline Soil & $\begin{array}{c}\text { Fr-Wt } \\
(\mathrm{gm} / 100 \\
\text { plant })\end{array}$ & $\begin{array}{c}\text { Dry-Wt } \\
(\mathrm{gm} / 100 \\
\text { plant })\end{array}$ & $\begin{array}{c}\text { Moisture } \\
(\%)\end{array}$ & $\begin{array}{c}\mathrm{N} \\
(\%)\end{array}$ & $\begin{array}{c}\mathrm{P} \\
(\%)\end{array}$ & $\begin{array}{c}\mathrm{K} \\
(\%)\end{array}$ & $\begin{array}{c}\mathrm{S} \\
(\%)\end{array}$ & $\begin{array}{c}\mathrm{Zn} \\
(\mathrm{mg} / \mathrm{kg})\end{array}$ & $\begin{array}{c}\mathrm{Cu} \\
(\mathrm{mg} / \mathrm{kg})\end{array}$ & $\begin{array}{c}\mathrm{Pb} \\
(\mathrm{mg} / \mathrm{kg})\end{array}$ & $\begin{array}{c}\mathrm{Cd} \\
(\mathrm{mg} / \mathrm{kg})\end{array}$ \\
\hline $\mathrm{C}$ & 679.50 & 62.50 & 90.79 & 1.88 & 0.49 & 7.78 & 0.17 & 30.98 & 27.35 & 0.17 & BDL \\
$\mathrm{T}$ & 791.25 & 83.25 & 89.44 & 2.14 & 0.39 & 5.78 & 0.14 & 407.82 & 45.03 & 5.00 & 2.05 \\
$\mathrm{R}$ & 840.50 & 85.75 & 89.79 & 2.22 & 0.56 & 7.12 & 0.13 & 300.03 & 49.62 & 2.67 & 0.92 \\
$\mathrm{~S}$ & 601.75 & 60.00 & 90.03 & 2.25 & 0.54 & 5.47 & 0.15 & 85.15 & 44.58 & 0.67 & 0.68 \\
LSD $_{0.05}$ & 126.20 & 11.88 & $\mathrm{NS}$ & 0.21 & 0.02 & 0.31 & 0.004 & 31.48 & 4.39 & 1.41 & 0.19 \\
\hline
\end{tabular}

$\mathrm{BDL}=$ Below detection limit, $\mathrm{NS}=$ Not significant, $\mathrm{C}=$ Control, $\mathrm{T}=$ Tejgaon, $\mathrm{R}=$ Rampura, $\mathrm{S}=$ Sitalakhya.

The physico-chemical changes of the soils receiving waste water irrigation are presented in Table 4. From the table it is seen that the $\mathrm{N}$ and $\mathrm{S}$ concentrations were lower than those of the background soil for both Tejgaon and Rampura soils. It could be due to higher uptake by the plants compared to the supply of these metals through waste water. The $\mathrm{P}$ concentration increased in the Tejgaon soil while the $\mathrm{K}$ concentration decreased slightly. However, a reverse trend for K concentration was noticed in the Rampura soil. For the Sitalakhya soil, the concentration of $\mathrm{N}$ and $\mathrm{S}$ were found lower than the background soil. The concentration of $\mathrm{Zn}$ substantially increased in the Rampura and Sitalakhya while in the Tejgaon soil it showed a decreasing tendency. There was practically no change in the $\mathrm{Cu}$ concentration in the Sitalakhya soil though it decreased in the Tejgaon and Rampura soils. Higher Pb concentration was found in the Rampura soil 
while in the Tejgaon and Sitalakhya soils the concentration of $\mathrm{Pb}$ decreased. $\mathrm{Cd}$ concentration increased in the Rampura and Sitalakhya soils but it did not show any change in the Tejgaon soil.

Table 4. Effect of waste water irrigation on soils under Kalmi.

\begin{tabular}{ccccccccccc}
\hline Soil & $\mathrm{pH}$ & $\begin{array}{c}\text { Org } \\
\mathrm{C}(\%)\end{array}$ & $\begin{array}{c}\text { Total N } \\
(\%)\end{array}$ & $\begin{array}{c}\text { Total P } \\
(\%)\end{array}$ & $\begin{array}{c}\text { Total K } \\
(\%)\end{array}$ & $\begin{array}{c}\text { Total S } \\
(\mathrm{mg} / \mathrm{kg})\end{array}$ & $\begin{array}{c}\text { Total Zn } \\
(\mathrm{mg} / \mathrm{kg})\end{array}$ & $\begin{array}{c}\text { Total Cu } \\
(\mathrm{mg} / \mathrm{kg})\end{array}$ & $\begin{array}{c}\text { Total Pb } \\
(\mathrm{mg} / \mathrm{kg})\end{array}$ & $\begin{array}{c}\text { Total Cd } \\
(\mathrm{mg} / \mathrm{kg})\end{array}$ \\
\hline $\mathrm{C}$ & 4.15 & 0.44 & 0.11 & 0.03 & 0.08 & 111 & 15.15 & 26.21 & 5.23 & $\mathrm{BDL}$ \\
$\mathrm{T}$ & 5.85 & 3.03 & 0.31 & 0.22 & 0.22 & 124 & 163.63 & 81.48 & 43.53 & 0.52 \\
$\mathrm{R}$ & 4.65 & 1.33 & 0.07 & 0.09 & 0.18 & 114 & 177.10 & 44.07 & 31.60 & 0.49 \\
$\mathrm{~S}$ & 6.48 & 0.35 & 0.05 & 0.13 & 0.23 & 108 & 113.16 & 36.69 & 14.07 & 0.08 \\
\hline
\end{tabular}

$\mathrm{BDL}=$ Below detection limit.

It is apparent from the data in Table 4 that almost all metal ions present in the background soil decreased after harvest. The control soil was irrigated with tap water for which reason the accumulation of the metals was almost nil. Another possible reason is that most of the metals were taken up by the plants from the soil.

The present research provides an assessment of the status of heavy metals in waste water and soil in the Tejgaon-Rampura-Sitalakhya water channel and the adjacent areas. The effect of waste water irrigation on Kalmi grown on soils from these areas revealed that the Tejgaon soils are the worst affected. Heavy metals accumulate in the Kalmi at levels greater than the recommended standard. Moreover, it also became apparent that the effluents discharged from the industries around the study area are not treated before these are released to the environment.

\section{Acknowledgement}

This work is a part of a research project financed by Ministry of Science and Information and Communication Technology, Govt. of the People's Republic of Bangladesh.

\section{References}

1. Alloway BJ and DC Ayres 1995. Chemical Principles of Environmental Pollution. Blackie Academic \& Professional, London. pp. 291.

2. Kibria MG, M Islam and M Alamgir 2012. Influence of waste water irrigation on heavy metal accumulation in soil and plant. International J. App. Natural Sci. 1: 43-54.

3. Siebe C and E Cifuentes 1995. Environmental impact of wastewater irrigation in central Mexico. International J. Environ. Health Res. 5: 161-173.

4. Kiziloglu FM, M Turan, U Sahin, I Angin, O Anapall and M Okuroglu 2007. Effects of waste water irrigation on soil and cabbage plant (Brassica olerecea var. capitate cv. Yalova-1) chemical properties. J. Plant Nutr. Soil Sci. 170: 166-172. 
5. Rattan RK, SP Datta, PK Chonkar, K Suribabu and AK Singh 2005. Long term impact of irrigation with sewage effluents on heavy metal contents in soil, crops and ground water. Agric. Eco. Environ. 109: 310-322.

6. Zoubi MM, A Arslan, G Abdelgawad, N Pejon, M Tabbaa and O Jouzdan 2008. The effect of sewage sludge on productivity of a crop rotation (of Wheat, Maize and Vetch) and heavy metals accumulation in soil and plant in Aleppo Governorate. American-Eurasian J. Agric. Environ. Sci. 3(4): 618-625.

7. Chen BH and YY Chen 1992. Determination of carotenoids and chlorophylls in water convovulus (Ipomoea aquatica) by liquid chromatography. Food Chem. 45: 129-134.

8. Prasad Nagendra K, GR Shivamurthy and SM Aradhya 2008. Ipomoea aquatica: An underutilized green leafy vegetable: A review. International J. Bot. 4: 123-129.

9. Kashem MA and BR Singh 2002. The effect of fertilizer additions on the solubility and plantavailability of Cd, Ni and Zn in soil. Nutr. Cycle Agroecosyst. 62: 287-296.

10. Gothberg A, M Greger, K Holm and BE Bengtsson 2004. Influence of nutrient levels on uptake and effects of mercury, cadmium and lead in water spinach. J. Environ. Qual. 33: 12471255.

11. Hossain Farzana, MTA Chowdhury and SM Imamul Huq 2011. Carbon economy and heavy metal contamination in two peri-urban areas of Dhaka city in relation to vegetable cultivation practices. Bangladesh J. Sci. Res. 23(2): 103-114.

12. Imamul Huq SM and MD Alam 2005. A Handbook on analysis of Soil, Plant and Water. BACERDU, University of Dhaka, Bangladesh. pp. 1-246. 